Abstract THU0208 - Table 1. Baseline characteristics

\begin{tabular}{|c|c|c|c|}
\hline & Bionaïve & $\begin{array}{c}\text { Bioexperience } \\
\text { (after antiTNF } \\
\text { failure) }\end{array}$ & $\mathbf{P}$ \\
\hline $\begin{array}{l}\text { Gender, female \% } \\
\text { Age, years, mean } \\
\text { (Q1-Q3) }\end{array}$ & $\begin{array}{c}78.3 \\
52.8(18-82)\end{array}$ & $\begin{array}{c}73.9 \\
54.8(19-82)\end{array}$ & $\begin{array}{l}\text { NS } \\
\text { NS }\end{array}$ \\
\hline $\begin{array}{l}\text { Disease duration, } \\
\text { years, mean (Q1- } \\
\text { Q3) }\end{array}$ & $5.8(0-37)$ & $8.0(1-33)$ & $<0.001$ \\
\hline $\begin{array}{l}>2 \text { yr } \\
\text { Never smoker } \%\end{array}$ & $\begin{array}{l}58.2 \\
68.4\end{array}$ & $\begin{array}{l}89.0 \\
69.2\end{array}$ & $\begin{array}{l}<0.001 \\
\text { NS }\end{array}$ \\
\hline $\begin{array}{l}\text { Seropositivity, \% } \\
\text { Erosions, \% }\end{array}$ & $\begin{array}{l}73.9 \\
47.6\end{array}$ & $\begin{array}{l}73.6 \\
61.9\end{array}$ & $\begin{array}{c}\text { NS } \\
0.023\end{array}$ \\
\hline $\begin{array}{l}\text { Comorbidities } \\
\text { (yes) \% }\end{array}$ & 32.7 & 40.9 & NS \\
\hline $\begin{array}{l}\text { Corticosteroids } \\
\text { (yes), \% }\end{array}$ & 72.8 & 63.6 & NS \\
\hline $\begin{array}{l}\text { Prior Biologic } \\
\text { Treatment \% }\end{array}$ & - & $\begin{array}{l}\text { Etanercept } 46.6 \\
\text { Adalimumab } 39.8 \\
\text { Infliximab } 11.4 \\
\text { Golimumab } 2.3\end{array}$ & \\
\hline $\begin{array}{l}\text { CZP monotherapy, } \\
\%\end{array}$ & 14.3 & 19.3 & NS \\
\hline $\begin{array}{l}>1 \text { concomitant } \\
\text { csDMARD, } \%\end{array}$ & 8.5 & 2.3 & 0.047 \\
\hline TJC, mean (SD) & $9.3( \pm 6.2)$ & $9.6( \pm 6.4)$ & NS \\
\hline SJC, mean (SD) & $6.7( \pm 4.7)$ & $7.2( \pm 5.8)$ & NS \\
\hline $\begin{array}{l}\text { CRP, mg/L, mean } \\
\text { (SD) }\end{array}$ & $6.6( \pm 15.8)$ & $9.2( \pm 14.7)$ & NS \\
\hline $\begin{array}{l}\text { ESR, mean (SD) } \\
\text { HAQ, mean (SD) }\end{array}$ & $\begin{array}{c}29.6( \pm 22.8) \\
1.2( \pm 0.7)\end{array}$ & $\begin{array}{c}30.1( \pm 24.5) \\
1.2( \pm 0.7)\end{array}$ & $\begin{array}{l}\text { NS } \\
\text { NS }\end{array}$ \\
\hline DAS28, mean (SD) & $4.7( \pm 1.1)$ & $4.7( \pm 1.1)$ & NS \\
\hline
\end{tabular}

Disclosure of Interest: None declared

DOI: 10.1136/annrheumdis-2018-eular.2846

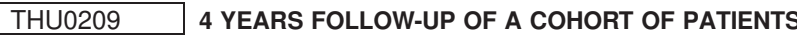 WITH RHEUMATOID ARTHRITIS IN SUSTAINED CLINICAL REMISSION AND OPTIMISATION OF BIOLOGICAL THERAPY}

M.L. Ladehesa Pineda ${ }^{1,2,3}$ M.C. Castro Villegas ${ }^{1,2,3}$, M. Romero Gómez $z^{1,2,3}$ L. Bautista Aguilar ${ }^{1,2,3}$, C. López Medina ${ }^{1,2,3}$, L. Pérez Sánchez ${ }^{1,2,3}$, I. Gómez García $^{1,2,3}$, P. Carreto Font ${ }^{4}$, A. Escudero Contreras ${ }^{1,2,3}$, E. Collantes Estévez ${ }^{1,2,3}$ P. Font Ugalde ${ }^{2,3} .{ }^{1}$ Rheumatology, Hospital Universitario Reina Sofía of Córdoba; ${ }^{2}$ IMIBIC; ${ }^{3}$ Universidad de Córdoba, Córdoba; ${ }^{4}$ Centro de Salud Tudela de Duero. Área Este de Valladolid, Valladolid, Spain

Background: The objectives of Rheumatoid Arthritis (RA) treatment comprise achieving persistent Clinical Remission (CR) or sustained low clinical activity. Nowadays management follows a "treat to target" strategy based on adjustment of treatment in accordance with protocolos. In patients with persistent disease activity after treatment with at least two of the classic disease-modifying antirheumatic drugs the use of biological therapy is recommended. Once sustained CR is achieved, the most efficient strategy is optimisation, by tapering the dose of the biological therapy or by increasing administration intervals. Searching for the lowest effective dose for each patient could minimise the risk of adverse effects and improve the cost-effectiveness of RA treatment.

Objectives: To proof that the performance of an optimisation strategy in patients with RA and sustained $C R$ under biological treatment maintains the proportion of patients with DAS28 $\leq 2,6$ after 4 years, to assess the maintenance of the effectivenes of the optimisation at 4 years in terms of clinical manifestations, and to analyse the time until relapse.

Methods: An open observational prospective study that included 70 patients with RA (CREATE registry) in CR at least for 6 months, under treatment with tapered dose of biological therapy (TNFi, abatacept or tocilizumab). Treatment effectiveness was assessed with the main variable DAS28 $\leq 2,6$. Statistical analysis included a descriptive study of variables and a confidence interval of $95 \%(95 \%$ $\mathrm{Cl}$ ) was estimated. For bivariate analysis, we used Student t-test for independent samples, repeated measures analysis of variance and mixed analysis of variance, and as a post-hoc contrast, Sidak adjustment. The log-rank test was used to compare the time until relapse according to the biological therapy.
Results: The mean age of the patients was $56,9(13,7)$ years, $78,6 \%$ were women, $68,8 \%$ were rheumatoid factor (RF) positive and $66,7 \%$ ACPA positive; the mean DAS28 at the beginning of the optimisation was 2,24 $(0,73)$. After 4 years, $27,7 \%(95 \% \mathrm{Cl}: 16,82 \%-38,58 \%)$ of patients maintained CR with the optimised dose, with a DAS28 2,15 $(0,81)$. Through the first year, the percentage of relapses was $15,71 \%$, in the second year, $7,35 \%$ and $4,61 \%$ relapsed during the third year. The median time of optimisation until relapse was $13,83^{3,18}$ months (95\% Cl:7,6-20,06). No significative differences were found at comparing the survival curves of the optimised patients until relapse for 4 years according to the biological therapy (TNFi vs no TNFi) (log-rank test:0,865, p:0,352) (graphic).

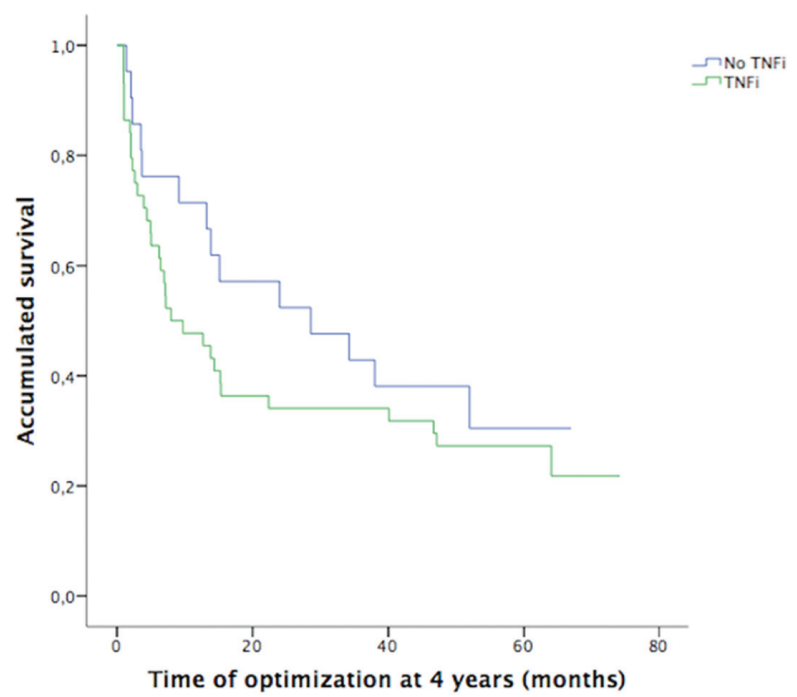

Conclusions: After 4 years, all of the patients maintained DAS28 levels of low disease activity, including those who had suffered a previous relapse and had turned back to the previous dose of biologic treatment. In view of this outcomes, optimisation strategy in clinical practice is posible and effective in patients with persistently controlled RA.

Disclosure of Interest: None declared

DOI: 10.1136/annrheumdis-2018-eular.5719

\section{THU0210 SAFETY, TOLERABILITY AND EFFICACY OF SUBCUTANEOUS TOCILIZUMAB ADMINISTERED AS MONOTHERAPY OR IN COMBINATION WITH CSDMARDS IN RHEUMATOID ARTHRITIS: RESULTS FROM THE OSCAR STUDY}

M. Safy ${ }^{1}$, M.J. De Hair ${ }^{1}$, M.E. Borm ${ }^{2}$, M.R. Kok ${ }^{3} .{ }^{1}$ Rheumatology and Clinical Immunology, University Medical Center Utrecht, Utrecht, ${ }^{2}$ Roche, Woerden; ${ }^{3}$ Rheumatology and Clinical Immunology, Maasstadziekenhuis, Rotterdam, Netherlands

Background: Efficacy and safety of intravenously (IV) administered tocilizumab (TCZ) in rheumatoid arthritis (RA) has been shown. Recently, efficacy and safety was confirmed for subcutaneous (SC) administration of TCZ. ${ }^{1}$ The possible effects of SC TCZ upon tapering of GCs/NSAIDs has not been investigated.

Objectives: First, to establish the safety and efficacy of SC TCZ monotherapy or in combination with csDMARDs in DMARD-IR RA. Second, to assess GC/NSAID dose reduction and/or discontinuation under SC TCZ treatment.

Methods: The OSCAR study was a Dutch multicenter, open-label, single arm phase IV study within the phase 4 TOZURA program. ${ }^{1}$ RA patients with an inadequate response (IR) to csDMARDS and 1 bDMARD were treated with weekly SC

Abstract THU0208 - Table 2. Effectiveness of CZP. Comparing at 12 months bionaïve and bioexperience groups

\begin{tabular}{|c|c|c|c|c|c|c|c|}
\hline & Bionaïve & $\begin{array}{c}\text { Baseline } \\
\text { Bioexperience (after antiTNF } \\
\text { failure) }\end{array}$ & Bionaïve & $\begin{array}{c}3 \text { months } \\
\begin{array}{c}\text { Bioexperience (after antiTNF } \\
\text { failure) }\end{array}\end{array}$ & Bionaïve & $\begin{array}{c}12 \text { months } \\
\text { Bioexperience (after antiTNF } \\
\text { failure) }\end{array}$ & $\mathrm{P}$ \\
\hline HAQ, mean (SD) & $1.2( \pm 0.7)$ & $1.2( \pm 0.7)$ & $1.1( \pm 0.7)$ & $1.1( \pm 0.7)$ & $0.9( \pm 0.6)$ & $0.9( \pm 0.7)$ & 0.925 \\
\hline DAS28, mean (SD) & $4.7( \pm 1.1)$ & $4.7( \pm 1.1)$ & $3.5( \pm 1.3)$ & $3.7( \pm 1.2)$ & $3.0( \pm 1.3)$ & $3.4( \pm 1.3)$ & 0.011 \\
\hline $\begin{array}{l}\text { Corticosteroids (yes), } \\
\%\end{array}$ & 72.8 & 63.6 & 61.8 & 56.8 & 43.8 & 45.5 & 0.780 \\
\hline DAS28 remission,\% & - & - & 25.2 & 17.9 & 45.5 & 32.1 & 0.031 \\
\hline DAS28 LDA, $\%$ & - & - & 43.6 & 31.0 & 61.7 & 45.2 & 0.008 \\
\hline EULAR Response,\% & - & - & 60.2 & 54.8 & 77.1 & 64.3 & 0.020 \\
\hline
\end{tabular}


injections of TCZ monotherapy or in combination with csDMARDs up to 24 weeks. From week 16 onwards dose reduction and/or discontinuation of glucocorticoids (GC) and NSAIDs was allowed. Primary endpoints were occurrence of adverse events (AEs), serious AEs (SAEs) and AEs of special interest (AESI). Secondary endpoints were time to GC/NSAID dose reduction and/or discontinuation, and DAS28 (remission), ACR 50 response, EULAR response, SDAI, CDAI and HAQDI. Occurrence of AEs was analysed using descriptive statistics. Changes over time in efficacy endpoints and response rates were analysed using Wilcoxon test. Results: Of the 150 patients 121 (81\%) patients completed the treatment period. In $91 \%$ of the patients there was $\geq 1 \mathrm{AE}$, in $9 \%$ an SAE, and in $4 \%$ an $\mathrm{AESI}$. Most AEs were mild or moderate in intensity and resolved without sequelae. Permanent TCZ treatment discontinuations due to AEs occurred in $7 \%$ of the 150 patients; of these, five patients were prematurely withdrawn from the study due to AEs. From week 16 onwards, $8(5.3 \%)$ and $13(8.7 \%)$ patients discontinued or reduced (for any reason) the dose of NSAIDs or GCs, respectively. Between weeks 16 and 20 , $2(1.3 \%)$ patients discontinued or reduced the dose of NSAIDs due to safety and other reasons. The dose of GCs was discontinued or reduced in 3 patients $(2.0 \%)$ between weeks 16 and 20, and in another 3 between weeks 20 and 24 (2,0\%), in all 6 patients mainly due to safety reasons (1.3\%), while NSAIDs dosage remained stable. The safety profile observed in this trial was in line with the known TCZ safety profile. Efficacy parameters improved over time for all of the endpoints. A selection of these results is shown in table 1.

Abstract THU0210 - Table 1. Efficacy results

Table. Efficacy results.

\begin{tabular}{|c|c|c|c|}
\hline \multicolumn{3}{|l|}{ Efficacy parameter } & \multirow{2}{*}{$\begin{array}{l}\text { P-value } \\
P<0.0001\end{array}$} \\
\hline Change from BL in DAS28, median (min, max) & & & \\
\hline Week 4 & 1.9 & $(1.10,-4.54)$ & \\
\hline Week 12 & -3.0 & $(0.89,-6.00)$ & \\
\hline Week 24 & 3.2 & $(-0.06,-7.57)$ & \\
\hline \multicolumn{4}{|l|}{ DAS28 remission, \% $(n / N)$} \\
\hline Week 4 & 52.1 & $(75 / 144)$ & \\
\hline Week 12 & 77.4 & $(103 / 133)$ & \\
\hline Week 24 & 86.8 & $(105 / 121)$ & \\
\hline ACR 50 response rate, \% & & & $P<0.0001$ \\
\hline Week 4 & 21.5 & & \\
\hline Week 12 & 45.1 & & \\
\hline Week 24 & 66.1 & & \\
\hline EULAR good response, $\%(n / N)$ & & & $P<0.0001$ \\
\hline Week 4 & 59.7 & $(86 / 144)$ & \\
\hline Week 12 & 85.0 & $(113 / 133)$ & \\
\hline Week 24 & 85.0 & $(113 / 133)$ & \\
\hline Change from $B L$ in SDAI, median ( $\min , \max$ ) & & & $P<0.0001$ \\
\hline Week 4 & -11.0 & $(-30.9,8.2)$ & \\
\hline Week 12 & 17.1 & $(-46.5,16.9)$ & \\
\hline Week 24 & -19.7 & $(-53.3,-0.07)$ & \\
\hline Change from $B L$ in CDAI, median ( $\min , \max )$ & & & $P<0.0001$ \\
\hline Week 4 & -9.1 & $(-30.8,8.3)$ & \\
\hline Week 12 & -15.1 & $(-45,16.9)$ & \\
\hline Week 24 & 17.3 & $(-60.2,0.1)$ & \\
\hline Change from $B L$ in HAQ-DI, median ( $\min , \max$ ) & & & $P<0.0001$ \\
\hline \multicolumn{3}{|l|}{ Week 4} & \\
\hline Week 12 & -0.25 & $(-1.25,1.13)$ & \\
\hline Week 24 & -0.38 & $(-2.13,0.38)$ & \\
\hline & -0.50 & $(-2.38,0.88)$ & \\
\hline
\end{tabular}

The median time of follow-up of the studied population was 822 days, IQR 429727 days.

Conclusions: The OSCAR study showed that SC TCZ is safe, well-tolerated and effective in RA patients with an inadequate response to csDMARDS and max 1 bDMARD. Importantly, a subset of patients could reduce GC and/or NSAID use during SC TCZ treatment. These findings support the notion that SC TCZ can be safely used in clinical practice.

\section{REFERENCE:}

[1] Choy E, et al. Rheumatology 2017. doi:10.1093/rheumatology/kex443

Disclosure of Interest: M. Safy Grant/research support from: AZ studentship grant, M. De Hair: None declared, M. Borm Employee of: Roche Nederland BV., M. Kok Consultant for: Roche B.V.

DOI: 10.1136/annrheumdis-2018-eular.6483

\section{THU0211}

SIX MONTHS AFTER TREATMENT DISCONTINUATION TNF IS STILL IN COMPLEX WITH ADALIMUMAB

M.J. I'Ami ${ }^{1}$, L.C. Berkhout ${ }^{2,3}$, M.T. Nurmohamed ${ }^{1,4}$, R.F. van Vollenhoven ${ }^{1,4,5}$, M. Boers ${ }^{4,6}$, J. Ruwaard ${ }^{1}$, F. Hooijberg ${ }^{1}$, T. Rispens ${ }^{2,3}$, G. Wolbink ${ }^{1,3}$. ${ }^{1}$ Amsterdam Rheumatology and immunology Center, location Reade; ${ }^{2}$ Immunopathology, Sanquin; ${ }^{3}$ Landsteiner Laboratory, Academic Medical Center, ${ }^{4}$ Amsterdam Rheumatology and immunology Center, location VU University Medical Center,

${ }^{5}$ Amsterdam Rheumatology and immunology Center, location Academic Medical Center, ${ }^{6}$ Epidemiology and Biostatistics, VU University Medical Center, Amsterdam, Netherlands

Background: Many patients with rheumatoid arthritis (RA) are successfully treated with tumour necrosis factor inhibitors (TNFi). We recently developed a novel assay that can quantify TNF in the presence of large amounts of TNFi, i.e. a 'drug-tolerant' assay. We showed in RA patients that TNF levels increased and stabilised during adalimumab treatment due to complex forming between TNF and adalimumab. In the presence of adalimumab, all TNF was in complex and biologically inactive. Once in remission, some patients can discontinue the TNFi for a prolonged period. It is unclear how long adalimumab levels are detectable and TNF complexes are formed after the last adalimumab administration.

Objectives: To investigate adalimumab levels and complexed TNF levels 6 months after the last adalimumab administration.

Methods: TNF and adalimumab levels were measured using a novel drug-tolerant competition enzyme-linked immunosorbent assay (ELISA), and a regular ELISA, respectively, in 11 consecutive RA patients with stable low disease activity (disease activity score of 28 joints $<3.2$ ) who discontinued adalimumab for 6 months (prior dose: $40 \mathrm{mg}$ every 2 weeks). Blood samples were drawn prior to adalimumab discontinuation and 3 and 6 months thereafter.

Results: After the last adalimumab administration, mean adalimumab leve decreased from 5.5 (SD 2.9) to 0.55 (0.52) and $0.11(0.13) \mu \mathrm{g} / \mathrm{mL}$ at 3 and 6 months after treatment discontinuation, respectively (figure 1A). In contrast, complexed TNF levels remained stable for prolonged periods of time: in 8 patients TNF levels at 3 months were indistinguishable from levels seen at baseline, on standard-dose adalimumab (figure 1B). After 6 months, TNF still remained stable in patients with adalimumab concentrations above $0.1 \mu \mathrm{g} / \mathrm{mL}(\mathrm{n}=4)$. Overall, mean TNF levels decreased from median 381 (inner quartiles 16; 707) to $290^{2 ; 755}$ and $83^{2 ; 532} \mathrm{pg} / \mathrm{mL}$ at 3 and 6 months after treatment discontinuation, respectively. In 5 patients, TNF levels decreased significantly. In those patients, adalimumab levels dropped to, or below the detection limit.
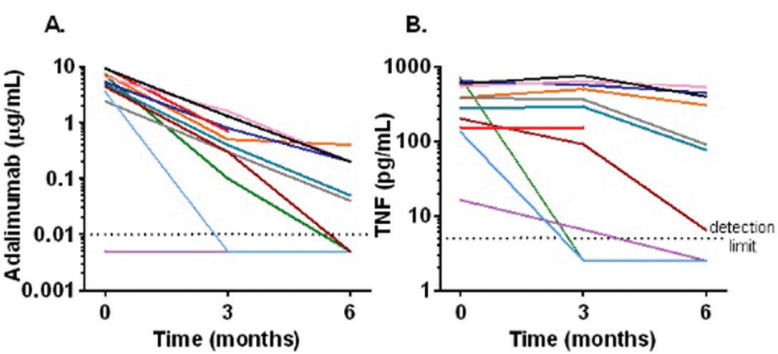

Conclusions: This is the first study showing that TNF is still in complex with adalimumab in the majority of patients 6 months after the last administration. Therefore, one may wonder at which point in time a patient has truly discontinued adalimumab treatment.

Disclosure of Interest: M. l'Ami: None declared, L. Berkhout: None declared, M. Nurmohamed Grant/research support from: Pfizer, AbbVie, Roche, BMS, MSD, Mundipharma, UCB, Janssen, Menarini, Eli Lilly, Sanofi, and Celgene, Speakers bureau: Pfizer, AbbVie, Roche, BMS, MSD, Mundipharma, UCB, Janssen, Menarini, Eli Lilly, Sanofi, and Celgene, R. van Vollenhoven Grant/research sup port from: AbbVie, BMS, GSK, Pfizer, UCB, Consultant for: AbbVie, AstraZeneca, Biotest, BMS, Celgene, GSK, Janssen, Lilly, Novartis, Pfizer, UCB, M. Boers: None declared, J. Ruwaard: None declared, F. Hooijberg: None declared, T. Rispens Grant/research support from: Genmab, Speakers bureau: Pfizer, AbbVie and Regeneron, G. Wolbink Speakers bureau: Pfizer, UCB, AbbVie, Biogen, BMS

DOI: 10.1136/annrheumdis-2018-eular.5526 